\title{
Microporus activated carbon fiber felt from Brazilian textile PAN fiber: preparation, characterization and application as super capacitor electrode
}

\section{Feltro de fibra de carbono ativado microporosa a partir de fibras PAN têxtil brasileira: preparação, caracterização e aplicação como eletrodo de super-capacitor}

Jossano Saldanha Marcuzzo ${ }^{1,2}$; Andres Cuña ${ }^{3}$; Nestor Tancredi3; Eduardo Mendez ; Heide Heloise Bernardi ${ }^{2,5}$;

Mauricio Ribeiro Baldan ${ }^{1}$

\begin{abstract}
Activated carbon fibers (ACF) are known as excellent adsorbent materials due to their fast adsorption rate and easy handling characteristic. The ACF can be manufactured from the polyacrylonitrile fiber, based on an usual carbon fibers (CF) production process accomplished by an additional activation process. The aim of the present work is to describe the production, chemical/morphological characterization and application potentiality of activated carbon fiber felt (ACFF) produced from textile PAN fiber, using a set of homemade equipment. The $5.0 \mathrm{dtex}$ PAN fiber tow with 200 thousand filaments was oxidized and used as raw material for felt production. The oxidized PAN fiber felt (OPFF) was displaced in a special sample holder, carbonized $\left(900{ }^{\circ} \mathrm{C}\right)$ and then activated in $\mathrm{CO}_{2}$ atmosphere at $1000{ }^{\circ} \mathrm{C}$ in an electric tubular furnace. All steps of the process were performed as fast as possible, and characterization was done by $77 \mathrm{~K}$ $\mathrm{N}_{2}$ isotherms, adsorption isotherms in liquid phase, scanning electronic microscope, X-ray diffraction and surface chemistry by Bhoem methodology. The results confirmed the production of essentially microporous (pore $<3.2 \mathrm{~nm}$, centered on $1.2 \mathrm{~nm}$ ) and $1,300 \mathrm{~m}^{2} \mathrm{~g}^{-1}$ surface area. The ACFF produced have demonstrated a strong potential application as electrode supercapacitor.
\end{abstract}

Keywords: Activated carbon fiber; Activated felt; Supercapacitor electrodes.

\begin{abstract}
RESUMO
Fibras de carbono ativado (FCA) são conhecidas por ser um excelente material adsorvente devido sua elevada cinética de adsorção e facilidade de manuseio. As FCA podem ser produzidas a partir da fibra de poliacriolonitrila e mesmo processo utilizado na fabricação de fibras de carbono, acoplando-se uma etapa de ativação ao final do processo. Neste trabalho é descrito a produção, caracterização química/morfológica e potencial aplicação de feltros de fibra de carbono ativado (FFCA), produzidos a partir de fibra PAN têxtil nacional em um equipamento experimental. Fibras PAN de 5.0 dtex em cabo de 200 mil filamentos foram oxidadas termicamente e utilizadas como matéria prima para a produção de feltro. O feltro de fibra PAN oxidada (FFPO) foi colocada em um porta amostra, especialmente desenhado, e inserido em um forno tubular elétrico, carbonizado $\left(900^{\circ} \mathrm{C}\right)$ e em seguida ativado em atmosfera de $\mathrm{CO}_{2}$ a $1000{ }^{\circ} \mathrm{C}$. Todas as etapas foram feitas na maior taxa possível e as caracterizações foram feitas por isotermas de $\mathrm{N}_{2}$ a $77 \mathrm{~K}$, a química de superfície foi analisada por titulação de Bhoem. Os resultados mostram um material essencialmente microporoso (poros < 3,2nm, concentrados em 1,2 nm) e $1300 \mathrm{~m}^{2}$ de área específica. O material produzido apresentou forte indicativo de aplicação como eletrodo de supercapacitor.
\end{abstract}

Palavras-chave: Fibra de carbono ativada; Feltro ativado; Eletrodo supercapacitor.

${ }^{1}$ Instituto Nacional de Pesquisas Espaciais - São José dos Campos (SP) - Brazil

${ }^{2}$ Faculdade de Tecnologia do Estado de São Paulo - São José dos Campos (SP) - Brazil

3Universidad del Uruguay - Laboratorio de Fisicoquímica de Superficies - Montevideo - Uruguay

${ }^{4}$ Universidad de la República - Facultad de Ciencias - Laboratorio de Biomateriales Montevideo - Uruguay

${ }^{5}$ Centro Nacional de Pesquisa em Energia e Materiais - Laboratório Nacional de Nanotecnologia - Campinas (SP) - Brazil

Correspondence author: Jossano Saldanha Marcuzzo - Instituto Nacional de Pesquisas Espaciais Av. dos Astronautas, 1.758 - Jardim da Granja CEP: 12227-010 - São José dos Campos (SP) - Brazil

Email: jossano@gmail.com

Received: 03/02/2016 Approved: 04/28/2016 


\section{INTRODUCTION}

Activated Carbons (AC) are one of the most widely used adsorbent materials around the world. Normally, AC is used for drinking and waste water treatment and in many other applications where the removal of generally dispersed contaminant molecules is desired ${ }^{(1)}$. AC also have important applications in energy storage such as a supercapacitors material of and Lithium-ion rechargeable Batteries ${ }^{(2)}$.

Activated carbon fibers (ACF) have special characteristics when compared with common activated carbons (granular or powder). They can be transformed into fabric, woven or yarn forms which give them self-sustainable characteristics. In addition, ACF show well defined pore structures on their surface which provides a high and fast adsorption capacity for specific components ${ }^{(3,4)}$. Facing the application as supercapacitor electrode, ACF have, in comparison with powdered activated carbons, advantages such as a high surface-area, a good electrical conductivity and easy electrode formation and containment ${ }^{(5)}$. In spite of all advantages of ACF applications, their use has been limited due to their relatively high cost.

One of the most important characteristics, which makes ACF a very special adsorbent material, is their pore size distribution. The architecture and structure of pores on ACF surface are characterized by a huge amount of micropores localized directly on the surface, leading to a faster and less energetic adsorption mechanism, especially for gases ${ }^{(6)}$.

The common methods used to produce ACF from a carbon fiber (CF) are not far from those used for AC production. The process can be simply described as a thermal treatment in an oxidant atmosphere at temperatures between 700 and $1000{ }^{\circ} \mathrm{C}^{(3,4,7)}$.

The ACF are highly quoted for adsorbent use, but it is very brittle and does not have enough mechanical resistance to be applied in normally used textile process. Consequently, it is very difficult to transform ACF in textile form. To solve this problem, oxidized textile PAN fiber was produced and then transformed into oxidized PAN fiber felt (OPFF). The OPFF was carbonized and activated to produce activated carbon fiber felt (ACFF).

\section{EXPERIMENTAL}

The commercial $200 \mathrm{k}$ tow of 5.0 dtex textile PAN fibers were oxidized in a laboratory scale oven set built, aiming an experimental production of flame resistant fibers. About $200 \mathrm{~kg}$ of oxidized PAN were produced and transformed in felt (OPFF) with $200 \mathrm{~g} \mathrm{~m}^{-2}$.

During the carbonization process, the oxidized PAN loses about $50 \%$ in mass and linearly shrinks $10 \%$. The shrinkage is an important parameter and must be controlled ${ }^{(8)}$, and for this purpose, an OPFF sample about $0.7 \mathrm{~m} \times 0.25 \mathrm{~m}$ was cut and displaced in a special sample holder that can control the sample shrinkage in two dimensions.
The set of such sample holder with felt was introduced in an electrical furnace (Figure 1). Both ends of the furnace tube were closed by flanges, which allow the insertion and the purge of argon gas to provide an inert atmosphere condition necessary for carbonization.

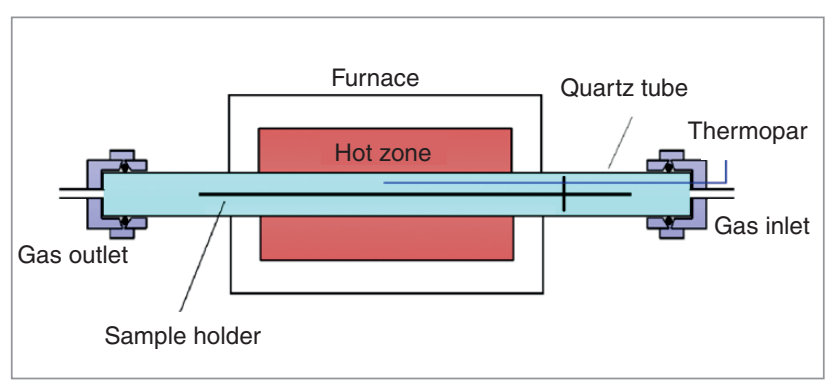

Figure 1: Carbonization and activation set up

The carbonization was performed in argon atmosphere at a final temperature of $900{ }^{\circ} \mathrm{C}$, applying the maximum heating rate attainable $\left(30^{\circ} \mathrm{C} \mathrm{min}^{-1}\right)$. The processing time for maximum temperature was set at $20 \mathrm{~min}$ for carbonization. The activation process was performed immediately after the carbonization by changing the argon to carbon dioxide and rising up the temperature to $1000{ }^{\circ} \mathrm{C}$; this temperature was maintained during $50 \mathrm{~min}$. The activation time was defined by a previous essay where the mechanical evaluation was done, and it was fixed at $50 \mathrm{~min}$ to guarantee the minimal mechanical characteristic for handling the activated fiber samples.

After finishing the carbonization and activation process, the gas was shifted again from $\mathrm{CO}_{2}$ to Ar and the furnace was turned off. This condition of inert atmosphere was maintained until the room temperature was achieved inside reactor.

The sample characterization was performed by $\mathrm{N}_{2}$ adsorption aiming the measurements of surface area and pore sizes distribution function. The nitrogen isotherm was performed at $77 \mathrm{~K}$ by Beckman Coulter SA 3100 equipment. The BET method was applied to determine the total surface area; the pore size distribution and the micropore volume were estimated by applying the NLDFT method ${ }^{(9)}$ over the adsorption isotherm. The burn-off was estimated weighing the sample before and after the activation process.

The methylene blue and iodine adsorption capacities were also determined in liquid media, due to the fact that these characteristics are normally used as a reference in the adsorbate industry. High resolution SEM was used to check surface fiber integrity. The structure of activated carbon fiber was analyzed by X-ray diffraction technique ${ }^{(10)}$ operated with monochromatic incident $\mathrm{Cu} \mathrm{Ka}\left(\lambda=1.5418 \mathrm{~A}^{\circ}\right)$ ray and an automatic data acquisition system. The carbon surface chemistry was evaluated by the titration method proposed by Boehm ${ }^{(11)}$.

For electrochemical characterization, a two-electrode Swagelok TM-type cells having two tantalum rods as current collectors were used. The electrodes $(6.3 \mathrm{mg})$ were prepared by a rectangular cut 
of the ACFF, with cross-section areas of $0.8 \mathrm{~cm}^{2}$ and thickness of $0.0015 \mathrm{~m}$. A glassy microfiber paper (Whatman $934 \mathrm{AH}$ ) was used as separator, and $2 \mathrm{M}$ aqueous $\mathrm{H}_{2} \mathrm{SO}_{4}$ electrolyte was used. Galvanostatic charges and discharges were performed at a current density in the range $1-10 \mathrm{~mA} \mathrm{~cm} \mathrm{c}^{-2}$, and at the voltage range of $0-1 \mathrm{~V}$. The cross-section area was used to determine the current density. The specific capacitance was determined according to the equation: $\mathrm{C}_{\mathrm{s}}=2 \times \mathrm{I} \times \mathrm{t}_{\mathrm{d}} / \mathrm{E}_{2} \times \mathrm{me}$, where $\mathrm{I}$ is the current applied, $t_{d}$ is the discharge time, $E_{2}$ is the voltage range during the discharge, and me is the mass of the electrode. The volumetric capacitance $\mathrm{C}_{\mathrm{v}}$ was determined according to the equation: $\mathrm{C}_{\mathrm{V}}=\mathrm{C}_{\mathrm{s}} \cdot \rho$, where $\rho$ is the bulk density of the ACFF. The bulk density was determined by measuring the weight and the geometrical dimensions of each electrode. The impedance measurements were carried out in the frequency range from $1 \mathrm{mHz}$ to $100 \mathrm{kHz}$ with a signal of amplitude of $15 \mathrm{mV}$. All the electrochemical measurements were carried out at room temperature and $2 \mathrm{M}$ of sulfuric acid as the electrolytic solution and the setup was VoltaLab PGZ301 equipment.

\section{RESULTS AND DISCUSSION}

The structural morphology of ACFF was studied by X-ray diffraction and scanning electronic microscopy. For pore structure analysis nitrogen gas adsorption at $77 \mathrm{~K}$ was determined. In additional, iodine and methylene blue isotherm were used to the determine adsorption capacity. For surface chemistry, Boehm methodology was applied ${ }^{(11)}$.

\section{$\mathrm{N}_{2}$ Isotherm}

Figures 2 and 3 show, respectively, the nitrogen gas adsorption isotherm at $77 \mathrm{~K}$ and pore size distribution function.

The nitrogen adsorption isotherm at $77 \mathrm{~K}$ (Figure 2) corresponds to a type I curve, with no hysteresis, and it shows that the gas saturation occurs at $0.2 \mathrm{P} / \mathrm{Po}$, indicating that this activated material is predominantly populated with micropores. The pore size distributions curve performed by NLDFT (Non local density function theory) methodology is shown in Figure 3, and it

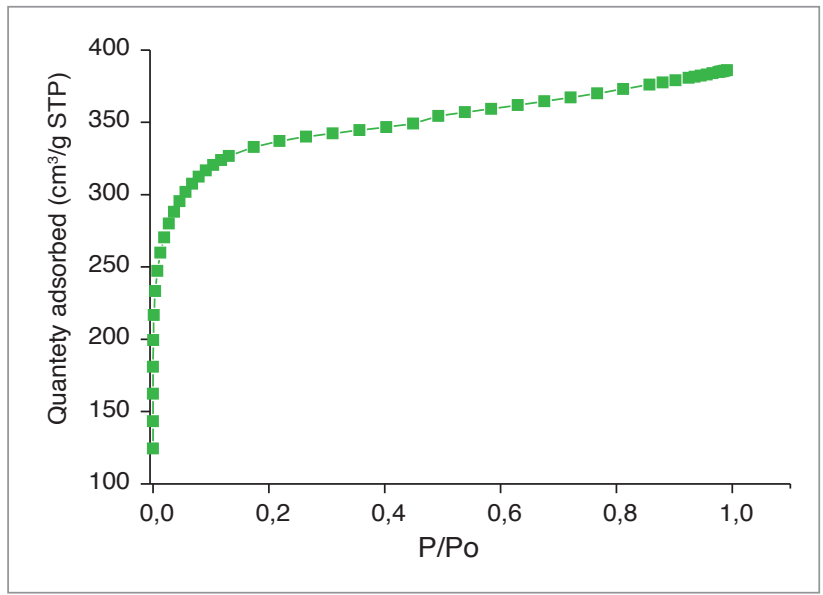

Figure 2: Nitrogen isotherm at $77 \mathrm{~K}$. clearly shows that the maximum pore width presented is around $3.2 \mathrm{~nm}$ and the predominant pores are sized at around $1.2 \mathrm{~nm}$. This technique does not give information about pores less than $1.0 \mathrm{~nm}$ in diameter, due to the $\mathrm{N}_{2}$ penetration limit, but it can be clearly observed in this curve that the distribution in the region for a size width less than $1 \mathrm{~nm}$ is ascendant in the direction of origin. This fact infers that the actual micropore volume and surface area of this material may be larger than those calculated by using these isotherms.

Table 1 presents the surface characteristics of activated carbon fiber felt obtained from textile PAN fiber, and the burn-off value of the activation process.

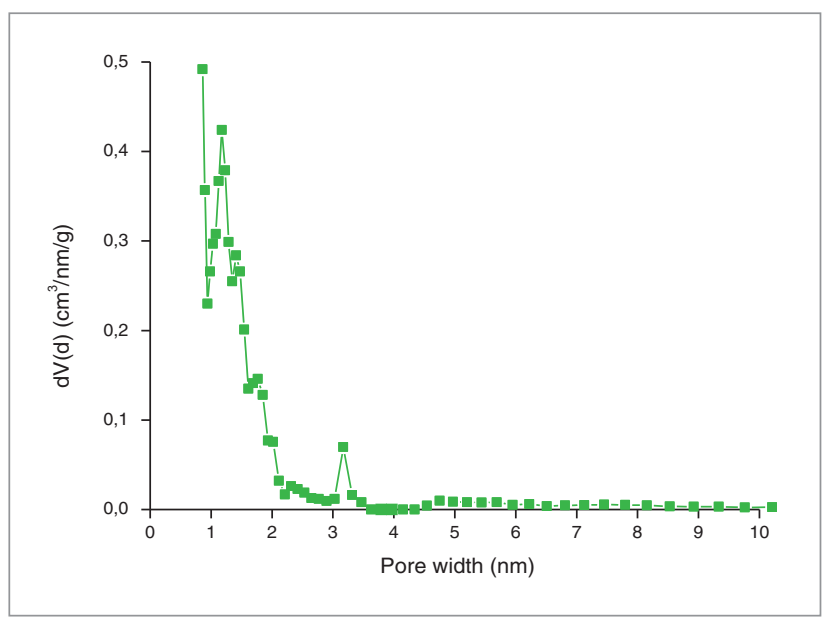

Figure 3:Pore size distribution by NLDFT (Non local density function theory)

Table 1:Surface characteristics of ACFF

\begin{tabular}{c|c|c|c|c} 
Sample & $\begin{array}{c}\text { Burn off } \\
(\mathbf{w} \%)\end{array}$ & $\begin{array}{c}\text { SBET } \\
\left(\mathbf{m}^{2} \mathbf{g}^{-1}\right)\end{array}$ & $\begin{array}{c}\text { Vmicropore } \\
\left(\mathbf{c m}^{3} \mathbf{~ g}^{-1}\right)\end{array}$ & $\begin{array}{c}\text { VTotal } \\
\left(\mathbf{c m}^{3} \mathbf{~ g}^{-1}\right)\end{array}$ \\
\hline ACFF & 35 & 1260 & 0,53 & 0,59 \\
\hline
\end{tabular}

\section{lodine and methylene blue Isotherm}

Iodine and methylene blue adsorption capacity of activated materials are parameters normally used to classify them as water pollutant organic compounds removing materials. Moreover, the adsorption capacity of iodine is associated to the presence of micropores sized between 0,5 and $1,5 \mathrm{~nm}^{(12)}$, while the methylene blue adsorption capacity is related to small mesopores ${ }^{(13)}$. For common activated carbon, the typical value of Iodine adsorption is around $1000 \mathrm{mg} \mathrm{g}^{-1}$ and methylene blue is between 100 and $350 \mathrm{mg} \mathrm{g}^{-1}$.

The iodine content for ACFF was determinate by ABNT/ MB-3410. The total Iodine adsorption was estimated in $1800 \mathrm{mg} \mathrm{g}^{-1}$. There isn't a standard to Methylene blue measurement, the common methodology to determine methylene blue in activated materials is by using spectrophotometer $(665 \mathrm{~nm})$ with silica sells of length $1 \mathrm{~cm}$. This methodology shows a $700 \mathrm{mg} \mathrm{g}^{-1}$ of methylene blue as ACFF adsorption content.

The amount of methylene blue and iodine ACFF adsorption is significant bigger then the value found for activated carbon on 
literature. This fact suggest that the ACFF is more efficient then activated carbon for small molecular compounds.

\section{Scanning electronic microscopy}

The carbonization heating rate used in this work is a rate not usually applied in the production of a material that essentially contains micropores. The usual heating rate is in the range of 1 to $10^{\circ} \mathrm{C} / \mathrm{min}^{(14)}$, while in this work it was used the maximum heating rate allowed for the furnace which was $30^{\circ} \mathrm{C} \mathrm{min}$. The choice of such high value for this process parameter has been assigned to the production of macropores, cracks and other surface damages, however the SEM analysis of fiber surfaces showed the surface integrity of activated samples.

Figure 4 shows the felt fibers distribution overview. The fibers are not broken for a small lengths. This is associated to their mechanical characteristics handling.

Figure 5 shows details of the carbon fiber filament. It can be observed that macropores, cracks, collapsed filaments and any other macroscopic surface impairment are absent. In addition,

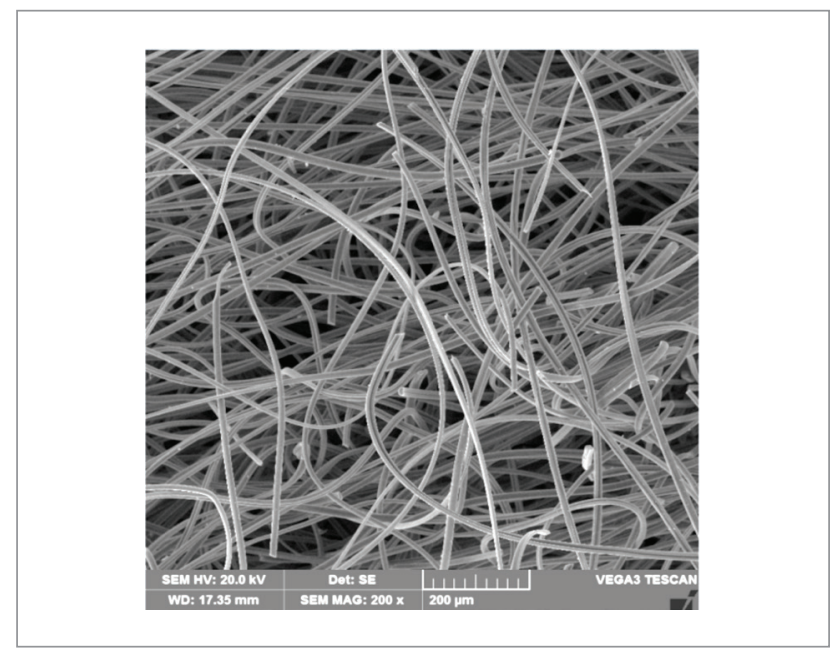

Figure 4: Filament structure ACFF overview.

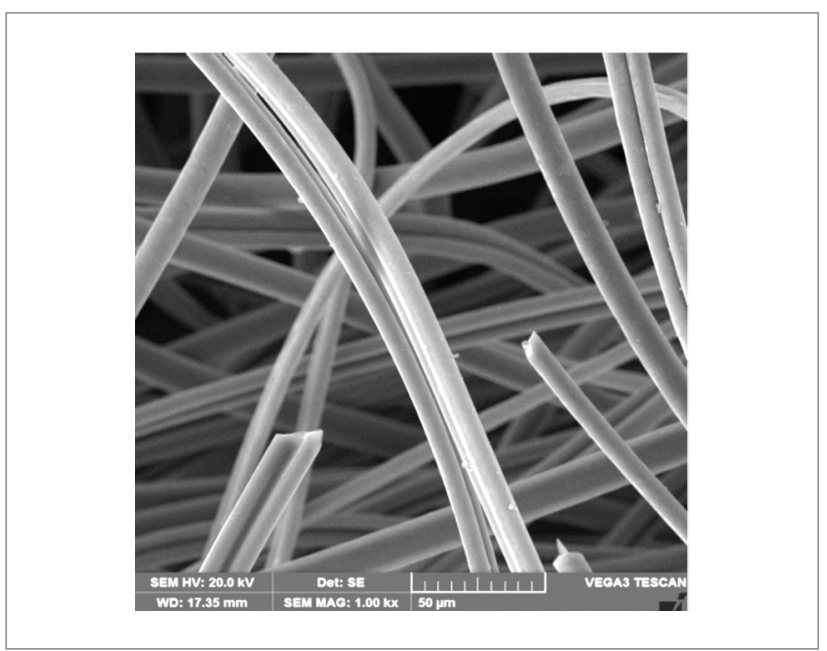

Figure 5: Detail of activated carbon fiber in the filament structure of activated carbon fiber felt. it can be said that the surface of activated fibers is clear and smooth.

As the ultimate surface damage analysis, the high resolution SEM image, with $150 \mathrm{k}$ magnification, is also provided and presented in Figure 6. This micrograph shows that the activated carbon fiber surface is exempted of macro-damages, which in turn indicates that the high heating rate doesn 't have any relationship with macropores or damage production on the activated carbon fiber surface.

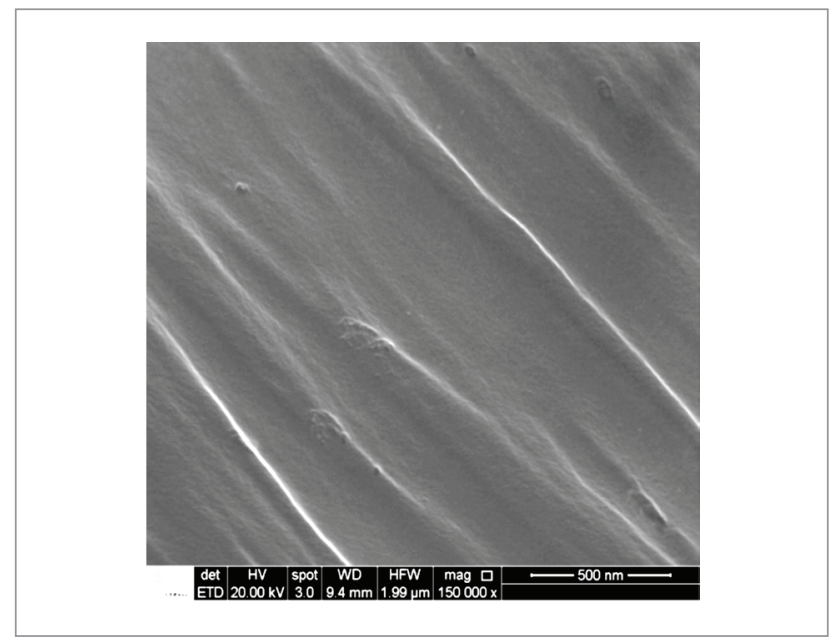

Figure 6: Magnification of $150 \mathrm{~K}$ on the activated carbon fiber.

\section{X-ray diffractogram (XRD)}

XRD of the activated carbon fiber felt is shown in Figure 7. The amorphous character of this fiber was confirmed. Two broad peaks appear at approximately $2 \theta=25^{\circ}$ and $44^{\circ}$. The first peak is associated with (002) line, while the second at $2 \theta=44^{\circ}$ is (100) line. The presence and the shapes of these two bands indicate that the activated carbon fiber (prepared by carbonization at $900{ }^{\circ} \mathrm{C}$ ) has a more organized aromatic structure with marked $\mathrm{sp}^{2}$ bonding character than other amorphous carbon, reported in the literature. These materials when prepared at lower

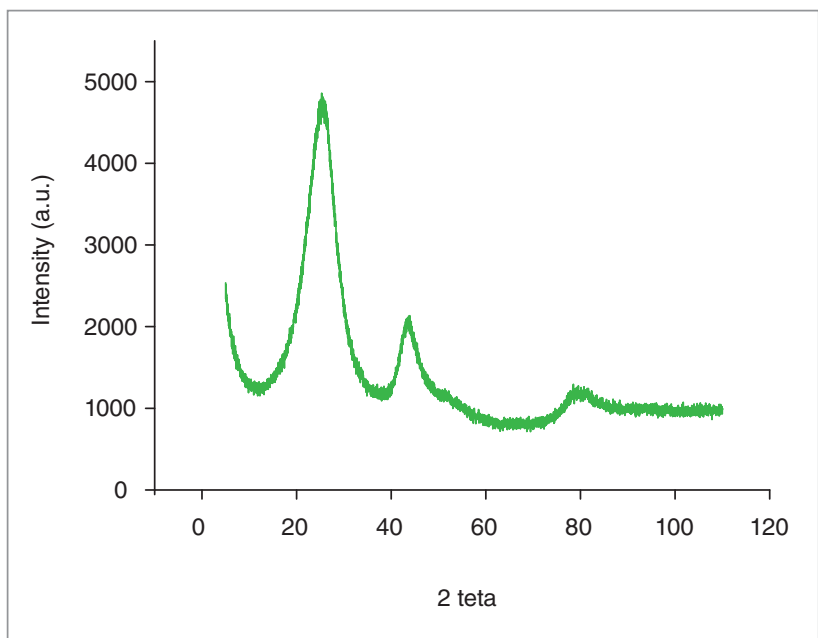

Figure 7: X-ray diffractogram of ACFF. 
temperature, such as the one used in this work, present higher $\mathrm{sp}^{3}$ bonding characteristic ${ }^{(10,15,16,17)}$.

Based on these results, it is expected that this fiber presents a relatively good electrical conductivity, what is an important characteristic for applications such as supercapacitor electrode manufacture ${ }^{(5,10,18)}$.

\section{Chemical surface by Boehm}

The wellknow Boehm methodology ${ }^{(11)}$ was used to investigate the activated carbon fiber felt surface chemistry. By using the Boehm titration it is possible to determine the amount of main acid groups as: carbonyl, carboxyl, phenolic, lactone, and also basic groups that there aren't detectable per species.

The results are presented on Table 2. It is possible to observe only two different species; however, the presence of carbonyl groups is much less prevalent than the basic groups that show a considerable amount. Consequently the activated carbon fiber felt surface has basic characteristics. This result indicates a basic behavior for aqueous applications.

Table 2: Surface chemistry by Boehm method.

\begin{tabular}{|c|c|c|c|c|c|}
\hline & Carbonyl & Carboxyl & Phenolic & Lactone & $\begin{array}{c}\text { Basic } \\
\text { groups }\end{array}$ \\
\hline $\mathrm{mmol} \mathrm{g}^{-1}$ & 0.2 & 0 & 0 & 0 & 0.5 \\
\hline
\end{tabular}

\section{Electrochemical characterization as supercapacitor electrode}

Figure 8 shows the specific capacitance Cs, and volumetric capacitance $\mathrm{Cv}$, as a function of the current density. The ACFF has a high Cs at low current densities $\left(200 \mathrm{~F} \mathrm{~g}^{-1}\right.$ at $\left.1 \mathrm{~mA} \mathrm{~cm}^{-2}\right)$, comparable to those reported for other carbon materials using the same electrolyte $e^{(5,10,18)}$. This was expected by its the high specific surface area $\left(1260 \mathrm{~m}^{2} \mathrm{~g}^{-1}\right)$ which gives a high double layer capacitance. A current density increase produces a drastic drop in the capacitance, which is mainly due to the high electrical resistance

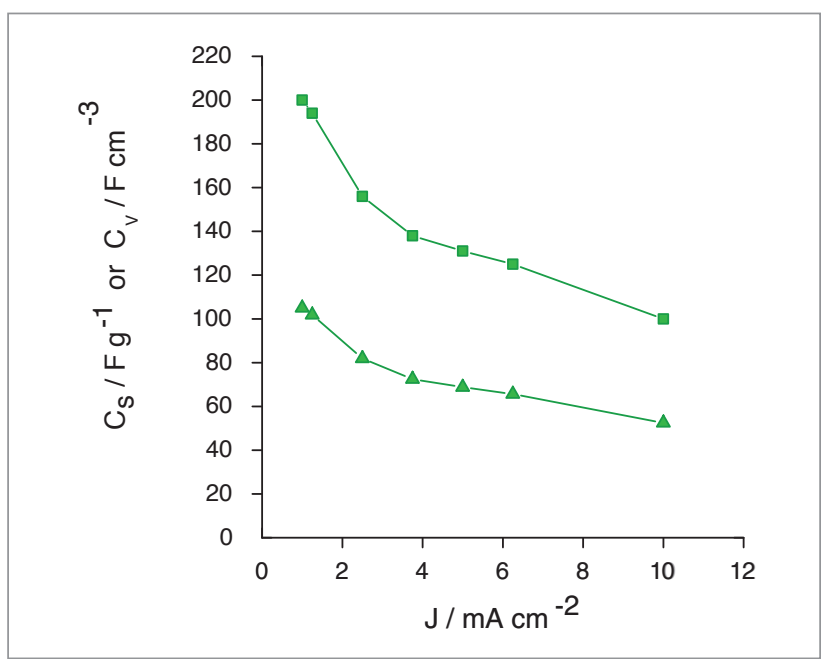

Figure 8: Variation of the specific capacitance Cs (squares) and the volumetric capacitance CV (triangles) with the current density. of the cell. This is demonstrated in the Nyquist plot (Figure 9) obtained from the electrochemical impedance measurements. In this plot, Rs is the ionic resistance of the electrolyte bulk and Ra is the arc resistance (Figure 9 inset). The total resistance of the cell can be defined as Ra+Rs. Ra can be linked to the electric resistance of the electrode plus the resistance of the electrode/ current collector contact ${ }^{(19)}$. For the ACFF studied in this work, Ra has a very high value $(125 \Omega)$, highest than the Rs $(2.7 \Omega)$. As discussed in section 3.3, it is expected that the activated fiber has a high electrical conductivity, but the poor connectivity between the fibers in the ACFF determine a high electrode resistance and electrode/current collector contact resistance ${ }^{(5)}$.

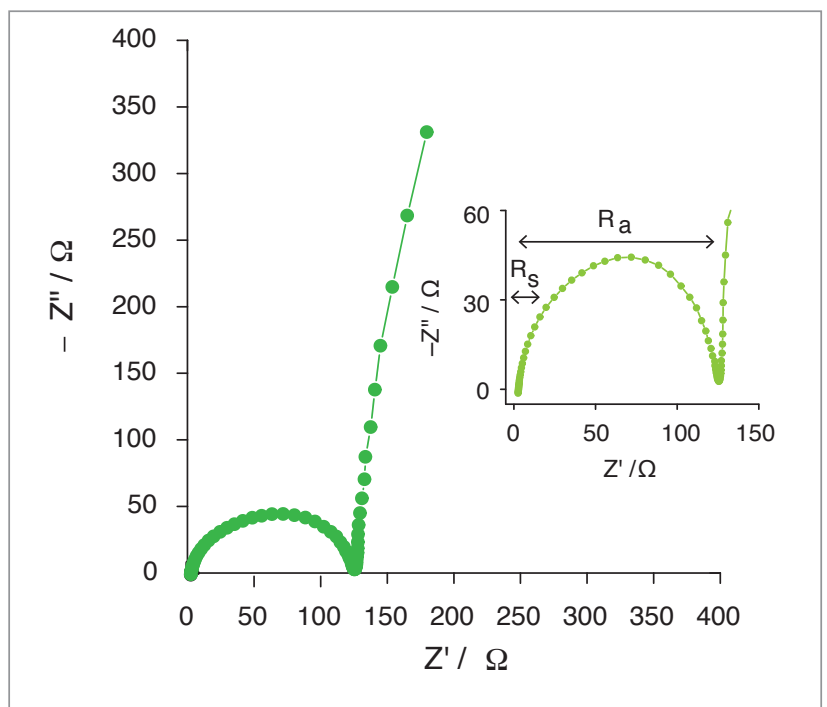

Figure 9: Nyquist diagram for the ACFF cell. Inset: magnification of the high-frequency region showing the arc. $\mathrm{Ra}$ is the arc resistance and $\mathrm{Rs}$ is the electrolyte bulk resistance.

The bulk density of the ACFF was $0.552 \mathrm{~g} \mathrm{~cm}^{-3}$. Given this value, $\mathrm{Cv}$ of the $\mathrm{ACFF}$ was determined for different current densities. At $1 \mathrm{~mA} \mathrm{~cm}^{-2}$, $\mathrm{Cv}$ was $104 \mathrm{~F} \mathrm{~cm}^{-3}$, slightly larger than those reported for bio carbon monoliths ${ }^{(18)}$ but significantly less than that reported for commercial carbon monoliths treated by different methods ${ }^{(20)}$. The biggest disadvantage of the ACFF is the drastic drop in capacitance at the highest current density.

\section{CONCLUSION}

It was proved that Oxidized PAN fiber felt can be transformed in a relatively high surface specific area activated material, with $1300 \mathrm{~m}^{2} \mathrm{~g}^{-1}$. Moreover, the heat treatment and the activation treatment parameters can be adjusted in a way that they drastically reduce the time and energy consumption for the manufacturing process.

The surface characterizations showed that the produced activated carbon fiber felt is a material populated essentially by micropores sized at $1.2 \mathrm{~nm}$, and with minor amount of 3.2 $\mathrm{nm}$ mesopores More work must be performed in the future 
to better describe the pore structure with sizes below $1 \mathrm{~nm}$, which was not accessed by nitrogen. XRD analysis shows that the activated carbon fibers do not present an ordered two dimensional structure. The activated carbon fiber felt produced from textile PAN fiber, is an interesting material for supercapacitor electrode application, it could be successfully used as a supercapacitor electrode material if its high electrical resistance can be reduced.

\section{ACKNOWLEDGMENT}

The authors want to acknowledge ITA for the conventional SEM images; the CNPEM/LNNano for the high resolution SEM images; and FAPESP Process 12/51087-6 and 09/52989-0 for the financial support.

\section{REFERENCES}

1. MARSH, H.; REINOSO, F.R., Activated Carbon, Elsevier, 2006

2. INAGAKI, M.; KANG, F.; TOYODA, M.; KONNO, H., Advanced Materials Science and Engineering of Carbon: USA, Tsinghua University Press Limited, 2014

3. SOLANO, A.L.; AMORÓS, D.C., in: Adsorption on Activated carbon fiber: Adsorption by carbon, Elsevier, 2008

4. YOON, S. H.; KORAY, Y.; MOCHIDA, I., in: Carbon Fibers and Activated Carbon fibers: Sciences of Carbon Materials. University of Alicante, 2000

5. PANDOLFO A.G., HOLLENKAMP A.F., Carbon properties and their role in supercapacitors. J. Power Sources 157, 11-27 (2006)

6. MOCHIDA, I.; KORAI, Y.; SHIRAHAMA, M.; KAWANO, S.; HADA, T.; SEO, Y.; YOSHIKAWA, M.; YASUTAKE, A., Renoval of SOx and NOx over activated carbon fiber. Carbon, v. 38, p. 227-239, 2000.

7. CARROTT, P.J.M.; NABAIS, J.M.V.; RIBEIRO CARROTT, M.M.L.; PAJARES, J.A., Preparation of activated carbon fibers from acrylic textile fibers, Carbon, v.39, p. 1543-1555, 2001.

8. MARCUZZO, J.S.; OTANI, C.; POLIDORO, H.A.; OTANI, S., Influence of Thermal Treatment on Porosity Formation on Carbon Fiber from Textile PAN. Materials Research. v. 16, p. 136-144, 2012.
9. TARAZONA, P., Solid-fluid transition and interfaces with density functional approaches. Surface Science, v. 94, p. 331-333, 1995

10. CUÑA, A.; TANCREDI, N.; BUSSI, J.; DEIANA, A.C.; SARDELLA, M.F.; BARRANCO, V.; ROJO, J.M. E., Grandis as a Biocarbons Precursor for Supercapacitor Electrode Application. Waste and Biomass Valor, 5:305-313 (2014)

11. BOEHM, H.P., Some aspects of the surface chemistry of carbon blacks and other carbons.Carbon, v.32 (5), pp. 759-769, 1994.

12. FERNANDEZ-COLINAS, J.; DENOYEL, R.; ROUQUEROL, J., Characterization of The Porosity of Activated Charcoals by Adsorption from Solution. Studies in Surface Science and Catalysis, v. 62, p. 399-408, 1991.

13. BAÇAOUI, A.; YAACOUBI, A.; DAHBI, A.; BENNOUNA, C.; PHAN TAN LUU, R.; MALDONADO-HODAR, F.J.; RIVERA-UTRILLA, J.; MORENO-CASTILLA, C., Optimization of conditions for the preparation of activated carbons from olive-waste cakes. Carbon, v. 39, p. $425-432,2001$

14. RONALDO M.A.; ROQUE-MALHERBE, Adsorption and diffusion in nanomaterials. USA: Taylor and Francis Group, 2007.

15. CELORRIO, V.; CALVILLO, L.; PÉREZ-RODRíGUEZ, S.; LÁZARO, M.J.; MOLINER, R., Modification of the properties of carbon nanocoils by different treatments in liquid phase. Micropor. Mesopor. Mat. v. 142, p. 55-61, 2011

16. KENNEDY, L.J.; VIJAYA, J.J.; SEKARAN, G., Effect of TwoStage Process on the Preparation and Characterization of Porous Carbon Composite from Rice Husk by Phosphoric Acid Activation.Ind. Eng. Chem. Res. v. 43, p. 1832-1838, 2004.

17. MOCHIDZUKI, K.; SOUTRIC, F.; TADOKORO, K.; ANTAL JR, M.J.; TOTH, M.; ZELEI, B.; VARHEGYI, G., Electrical and Physical Properties of Carbonized Charcoals. Ind. Eng. Chem. Res. v. 42, p. 5140-5151, 2003

18. CUÑA, A,; TANCREDI, J.B.N.; BARRANCO, V. ; CENTENO,T.A. QUEVEDO, A,; ROJO, J.M., Biocarbon Monoliths as Supercapacitor Electrodes: Influence of Wood Anisotropy on Their Electrical and Electrochemical Properties. Journal of The Electrochemical Society, 161 (12) A1806-A1811 (2014).

19. GARCÍA, A.: MILES, P; CENTENO, T.A.; ROJO, J. M., Uniaxially oriented carbon monoliths as supercapacitor electrodes. Electrochimica Acta, 55, 8539 (2010).

20. KUNOWSKY, M.; GARCIA, A.; BARRANCO, V.; ROJO, J.M.; IBAÑEZ, J.; CARRUTHERS, D.; LINARES-SOLANO, A., Dense carbon monoliths for supercapacitors with outstanding volumetric capacitances Carbon, 68, 553 (2014) 